Jurnal Penelitian,Vol. 11, No. 2, Agustus 2017

\title{
PEMIKIRAN PENDIDIKAN KI. HAJAR DEWANTARA DAN RELEVANSINYA DENGAN KURIKULUM 13
}

\author{
Eka Yanuarti \\ STAIN Curup, Bengkulu, Indonesia \\ ekayanuarti14@gmail.com
}

\begin{abstract}
The progress in education side today, cannot be separated from the role of figures as the main actor. The figure who has a major contribution to the development of education in Indonesia and become a Father of National Education that is KI. Hajar Dewantara, This study is a library research by using content analysis approach. His thought about education is relevant to the K13, such as learning objectives, which are aimed at educational goals in four dimensions, physical, intellectual, spiritual and social objectives. The purpose of education is; equally directing educational goals relating to individuals and society, but in $K 13$ the objectives itself are further related to the nation and state, even the civilization of the world. The role of educators according to KI. Hajar Dewantara as facilitator and motivator. Meanwhile, according to the k13 the role of educator itself as a facilitator in learning and as a learning partner for learners. Both agree that there are four competencies that must be owned by an educator, namely pedagogic, personality, social and professional. The principle of learning in the
\end{abstract}


K13 also related to the Father of National Education's learning principles. He stated that there are five principles itself: the principle of independence, the principle of nationality, the principle of culture, the principle of nature and the principle of bumanity. Furthermore, in the learning materials both agreed that learning materials are tanght in accordance with the level of development of the age of learners. Both of them put the subjects of education of Religion and Character in every level of the educational unit.

Keywords: Educational concept, Ki. Hajar Dewantara, Curriculum 2013 (K13)

\begin{abstract}
Abstrak
Kemajuan dunia pendidikan saat ini, tidak dapat dilepaskan dari peran tokoh sebagai aktor utama. Tokoh yang memiliki sumbangsi besar untuk kemajuan pendidikan di Indonesia dan mendapat gelar sebagai Bapak Pendidikan Nasional yaitu Ki. Hajar Dewantara, Penelitian ini merupakan kajian studi pustaka (library research) dengan menggunakan pendekatan content analysis (analisis isi). Pemikiran pendidikan Ki. Hajar Dewantara relevan dengan kurikulum 2013 seperti tujuan pembelajaran, yaitu sama-sama mengarabkan tujuan pendidikan dalam empat dimensi, yaitu tujuan jasmani, akal, rohani dan sosial. Tujuan pendidikan yaitu; samasama mengarabkan tujuan pendidikan berkaitan dengan individu dan masyarakat, Peran pendidik menurut Ki. Hajar Dewantara sebagai fasilitator dan motivator. Sementara menurut kurikulum 2013 peran pendidik juga sebagai fasilitator dalam pembelajaran dan sebagai mitra belajar bagi peserta didik. Keduanya sepakat bahwa ada empat kompetensi yang harus dimiliki seorang pendidik, yaitu pedagogik, kepribadian, sosial dan profesional. Prinsip pembelajaran yang ada di kurikulum 2013 relevan dengan prinsip pembelajaran menurut Ki. Hajar dewantara, yaitu: prinsip kemerdekaan, prinsip kebangsaan, prinsip kebudayaan, prinsip kodrat alam, prinsip kemanusiaan. Selanjutnya mengenai materi pembelajaran keduanya sepakat materi pembelajaran diajarkan sesuai dengan tingkat perkembangan usia peserta didik. Keduanya meletakkan mata pelajaran pendidikan Agama dan Budi Pekerti di setiap jenjang satuan pendidikan.
\end{abstract}

Kata Kunci: Pemikiran Pendidikan, Ki. Hajar Dewantar, Kurikulum 2013 
Pemikiran Pendidikan Ki. Hajar Dewantara dan Relevansinya....

\section{A. Pendahuluan}

Pendidikan memegang peranan penting dalam memajukan suatu bangsa, sejak zaman perjuangan kemerdekaan dahulu, para pejuang serta perintis kemerdekaan telah menyadari bahwa pendidikan merupakan faktor yang sangat vital dalam usaha untuk mencerdaskan kehidupan bangsa serta membebaskannya dari belenggu penjajahan. Oleh karena itu, mereka berpendapat bahwa disamping melalui organisasi politik, perjuangan ke arah kemerdekaan perlu dilakukan melalui jalur pendidikan. Pendidikan dijadikan media untuk mengembangkan kemampuan dan membentuk watak serta peradaban bangsa yang bermartabat dalam rangka mencerdaskan kehidupan bangsa, bertujuan untuk mengembangkan potensi peserta didik agar menjadi manusia yang beriman dan bertakwa kepada Tuhan Yang Maha Esa, berakhlak mulia, sehat, berilmu, cakap, kreatif, mandiri, dan menjadi warga Negara yang demokraris serta bertanggung jawab. Untuk mengemban fungsi tersebut pemerintah menyelenggarakan suatu sistem pendidikan nasional sebagaimana tercantum dalam Undang-Undang No. 20 Tahun 2003 tentang Sistem Pendidikan Nasional. ${ }^{1}$

Kemajuan dunia pendidikan saat ini, tidak dapat dilepaskan dari peran tokoh sebagai aktor utama. Para pendidik telah memainkan peranan yang amat signifikan dengan cara mendirikan lembaga pendidikan mulai dari tingkat Taman Kanak-kanak, hingga Perguruan Tinggi atau Universitas. Di lembaga-lembaga pendidikan tersebut, mereka telah mengembangkan sistem dan pendekatan dalam proses belajar mengajar, visi dan misi yang harus diperjuangkan, kurikulum, bahan ajar berupa buku-buku, majalah, dan sebagainya, gedung-gedung tempat berlangsungnya kegiatan pendidikan lengkap dengan sarana prasarananya, tradisi dan etos keilmuan yang dikembangkan, sumber dana dan kualitas lulusan yang dihasilkan.

${ }^{1}$ Afnil. Guza, Undang-Undang Sistem Pendidikan Nasional dan Undang-U dang Guru dan Dosen) Jakarta; Asa Mandiri, 2009), hlm. 5 


\section{Eka Yanuarti}

Tokoh yang memiliki sumbangsih besar untuk kemajuan pendidikan di Indonesia dan mendapat gelar sebagai Bapak Pendidikan Nasional yaitu Ki. Hajar Dewantara, Ia adalah aktivis pergerakan kemerdekaan Indonesia, kolumnis, dan pelopor pendidikan bagi bangsa Indonesia. Sepanjang perjalanan hidupnya sarat dengan perjuangan dan pengabdian demi kepentingan bangsa. Tak heran jika peran dan jasanya begitu besar dalam mengawal impian bangsa Indonesia untuk menjadi bangsa yang merdeka dari segala macam bentuk penjajahan.

Untuk mengawal impian tersebut, ia menggunakan media pendidikan, baginya pendidikan bukanlah tujuan, melainkan media untuk mencapai tujuan perjuangan yaitu mewujudkan manusia Indonesia yang merdeka lahir dan batin. Merdeka lahiriah berarti tidak dijajah secara fisik, ekonomi, politik dan lain-lain, sedangkan merdeka batiniah berarti mampu mengendalikan diri dan mandiri dangan tanpa melanggar kemerdekaan orang atau golongan lain. $^{2}$

Pemikiran pendidikan Ki Hajar Dewantara telah menarik banyak penulis untuk menuangkannya dalam bentuk artikel jurnal, seperti yang ditulis Wawan Eko Mujito dengan kesimpulan konsep belajar dalam pandangan Ki Hajar Dewantara relevan dengan Pendidikan Agama Islam³ ${ }^{3}$ Kemudian jurnal yang ditulis Muthoifin dengan kesimpulan Pemikiran pendidikan multikultural Ki Hadjar adalah bercorakkan nasionalistik dan universal. ${ }^{4}$

Seiring dengan itu sudah tiba waktunya bagi kita untuk mengkaji gagasan, pemikiran dan pendapat dari pemikiran pendidikan masa lalu untuk dijadikan masukan bagi penyusunan konsep pendidikan masa depan seperti pengembangan dan

${ }^{2}$ Suparto Rahardjo. Biografi Singkat Ki. Hajar Dewantara, 1889-1959. (Y gyakarta: Garasi, 2009), hlm. 6

${ }^{3}$ Wawan Eko Mujito, Konsep Belajar Menurut Ki Hadjar Dewantara dan Relevansinya dengan Pendidikan Agama Islam, Jurnal Pendidikan Agama Islam, Vol. XI, No. 1, Juni 2014, hlm. 75.

${ }^{4}$ Muthoifin, Pemikiran Pendidikan Multikultural Ki Hadjar Dewantara, Jurnal Intizar, Vol. 21, No. 2, 2015, hlm. 317 
implementasi kurikulum 2013. Kemajuan ilmu pengetahuan, teknologi, dan kemajuan masyarakat mempengaruhi perubahan kurikulum. Tidak bisa dipungkiri bahwa perubahan kurikulum selalu mengarah pada perbaikan sistem pendidikan. Perubahan tersebut dilakukan karena dianggap belum sesuai dengan harapan yang diinginkan sehingga perlu adanya revitalisasi kurikulum. Usaha tersebut mesti dilakukan demi menciptakan generasi masa depan berkarakter, yang memahami jati diri bangsanya dan menciptakan anak yang unggul, mampu bersaing di dunia internasional. Sebagaimana hasil tesis yang ditulis Restu Sani Izzati $^{5}$ dengan hasil Peserta Didik Berkebutuhan Khusus (PDBK) di Sekolah Dasar Inklusif Klampis Ngasem 1/246 dalam memberikan pembelajaran kepada siswa peserta didik berkebutuhan khusus dalam pembelajaran kurikulum 2013 yaitu kurang efektif. Selanjutnya penelitian Prastian Dwija Permana dengan hasil hasil belajar siswa pada materi pengelasan yang menggunakan kurikulum 2013 lebih baik dari pada pembelajaran konvensional. ${ }^{6}$

Berdasarkan pemaparan di atas, diketahui literasi terkait pemikiran Ki Hajar Dewantara dan kurikulum 2013 telah banyak disajikan, tetapi belum ada yang menyandingkan pemikiran pendidikan Ki. Hajar Dewantara dan kurikulum 2013. Pada penelitian ini, peneliti memfokuskan tentang bagaimana pemikiran pendidikan Ki. Hajar Dewantara dan relevansinya dengan kurikulum 2013.

${ }^{5}$ Restu Sani Izzati, Implementasi Kurikulum 2013 bagi Peserta Didik Berkeb tuhan Khusus Disekolah Dasar Inklusif, Pendidikan Luar Biasa, Fakultas Ilmu Pendidikan, Universitas Negeri Surabaya, 2015, hlm. 8

${ }^{6}$ Prastian Dwija Permana, "Pengaruh Penerapan Kurikulum 2013 terhadap Hasil Belajar Mata Diklat Pengelasan Kelas X TKR di SMK Negeri 1 Sedan Rembang Tabun Ajaran 2013/2014"( Universitas Negeri Semarang; urusan Teknik Mesin Fakultas'Teknik, 2013), hlm.vii. 


\section{B. Pembahasan}

\section{Pemikiran Pendidikan Ki. Hajar Dewantara}

a. Biografi Ki. Hajar Dewantara

Ki. Hajar Dewantara terlahir dengan nama Raden Mas Suwardi Suryaningrat pada 2 Mei 1889. Ia berasal dari lingkungan keluarga keraton, tepatnya pura Pakualaman, Yogyakarta. Ki. Hajar Dewantara merupakan cucu dari Sri Paku Alam III, sedangkan ayahnya bernama K.P.H. Suryaningrat dan Ibundanya bernama Raden Ayu Sandiyah yang merupakan buyut dari Nyai Ageng Serang, seorang keturunan dari Sunan Kalijaga. ${ }^{7}$

Raden Mas Suwardi Suryaningrat kemudian berganti nama di usianya yang ke 39 tahun, ia berganti nama menjadi Ki Hadjar Dewantara. Lingkungan hidup pada masa Ki Hajar Dewantara kecil sangat besar pengaruhnya terhadap jiwanya yang sangat peka terhadap kesenian dan nilai-nilai kultur maupun religius. ${ }^{8}$ Setelah berganti nama dengan Ki Hajar Dewantara dapat leluasa bergaul dengan rakyat kebanyakan. Sehingga dengan demikian perjuangannya menjadi lebih mudah diterima oleh rakyat pada masa itu. ${ }^{9}$

Tanggal 4 November 1907 dilangsungkan "Nikah Gantung" antara R.M. Soewardi Soeryaningrat dengan R.A. Soetartinah. Keduanya adalah cucu dari Sri Paku Alam III. Pada akhir Agustus 1913 beberapa hari sebelum berangkat ke tempat pengasingan di negeri Belanda. Pernikahannya diresmikan secara adat dan sederhana di Puri Suryaningratan Yogyakarta. ${ }^{10}$ Jadi Ki Hadjar Dewantara dan

${ }^{7}$ Suparto Rahardjo, Op.Cit., hlm. 9

${ }^{8}$ Ki Hariyadi. Ki Hadjar Dewantara sebagai Pendidik, Budayawan, Pemimpin Rakyat dalam Buku Ki Hadjar Dewantara dalam Pandangan Para Cantrik dan Mentriknya, (Yogyakarta: MLTS,1989), hlm. 132

${ }^{9}$ Darsiti Soeratman, Ki Hadjar Dewantara, (Jakarta: Departemen Pendid kan dan Kebudayaan, 1983/1984), hlm. 171.

${ }^{10}$ Hah. Harahap dan Bambang Sokawati Dewantara. Ki Hadjar Dewantara dan Kawan-Kawan, Ditangkap, Dipenjara, dan Diasingkan, Jakarta: Gunung Aguna, 1980), hlm. 12. 
Nyi Hadjar Dewantara adalah sama-sama cucu dari Paku Alam III atau satu garis keturunan.

Ki Hadjar Dewantara meninggal dunia pada tanggal 26 Apri 1959, di rumahnya Mujamuju Yogyakarta. Tanggal 29 April, jenazah Ki Hadjar Dewantara dipindahkan ke pendopo Taman Siswa. Dari pendopo Taman Siswa, kemudian diserahkan kepada Majelis Luhur Taman Siswa. Dari pendopo Taman Siswa, jenazah diberangkatkan ke makan Wijaya Brata Yogyakarta. Dalam upacara pemakaman Ki Hadjar Dewantara dipimpin oleh Panglima Kodam Diponegoro Kolonel Soeharto. ${ }^{11}$

Tanggal 28 November 1959, Ki Hadjar Dewantara ditetapkan sebagai "Pahlawan Nasional". Tanggal 16 Desember 1959, pemerintah menetapkan tanggal lahir Ki Hadjar Dewantara tanggal 2 Mei sebagai "Hari Pendidikan Nasional” berdasarkan keputusan Presiden RI Nomor: 316 tahun 1959. ${ }^{12}$ Sebagai tokoh nasional yang dihormati dan disegani baik oleh kawan maupun lawan, Ki Hadjar Dewantara sangat kreatif, dinamis, jujur, sederhana, konsisten, konsekuen dan berani. Wawasan beliau sangat luas dan tidak berhenti berjuang untuk bangsanya hingga akhir hayat. Perjuangan beliau dilandasi dengan rasa ikhlas yang mendalam, disertai rasa pengabdian dan pengorbanan yang tinggi dalam mengantarkan bangsanya ke alam merdeka. ${ }^{13}$

b. Pendidikan Ki. Hajar Dewantara

Selain mendapat pendidikan di lingkungan Istana Paku Alam, Ki. Hajar Dewantara juga mendapatkan pendidikan agama dari pesantren Kalasan di bawah asuhan KH. Abdurahman. ${ }^{14}$ Setelah itu tersebut, Ki Hadjar Dewantara juga mendapat pendidikan formal antara lain: ${ }^{15}$ ELS (Europeesche Legere School). Sekolah Dasar

${ }^{11}$ Ki Hadjar Dewantara, Karya Bagian I: Pendidikan, (Yogyakarta: MLPTS, cet II, 1962), hlm. 137.

${ }^{12}$ Ibid, hlm. XIII

${ }^{13}$ Ki Hariyadi, Op.Cit., hlm. 39.

${ }^{14}$ Suparto Rahardjo, Op.Cit, hlm. 9

${ }^{15}$ Gunawan, Berjuang Tanpa Henti dan Tak Kenal Lelah Dalam Buku Pering - 


\section{Eka Yanuarti}

Belanda III. Kweek School (Sekolah Guru) di Yogyakarta. STOVIA (School Tot Opvoeding Van Indische Artsen) yaitu sekolah kedokteran yang berada di Jakarta. Pendidikan di STOVIA ini tak dapat diselesaikannya, karena Ki Hadjar Dewantara sakit selama 4 bulan. Europeesche Akte, Belanda 1914.

c. Karya-Karya Ki. Hajar Dewantara

Adapun karya-karya Ki Hadjar Dewantara antara lain adalah: buku bagian pertama: tentang Pendidikan, buku bagian kedua: tentang Kebudayaan, buku bagian ketiga: tentang Politik dan Kemasyarakatan, buku bagian keempat: tentang Riwayat dan Perjuangan Hidup Penulis: Ki Hadjar Dewantara. ${ }^{16}$

\section{Kurikulum 2013}

\section{a. Urgensi Kurikulum 2013}

Diberlakukannya kurikulum 2013 ada 3 hal yang urgen. Pertama, butuh penekanan agar materi pelajaran sesuai dengan tahap perkembangan peserta didik; Kedua, perlunya pembelajaran yang mampu mengembangkan kreatifitas siswa; Ketiga, masih sangat diperlukannya Pendidikan karakter. ${ }^{17}$ Pengembangan kurikulum perlu dilakukan karena adanya berbagai tantangan yang dihadapi, baik tantangan internal maupun tantangan eksternal, penyempurnaan pola pikir, penguatan tata kelola kurikulum, dan pendalaman dan perluasan materi. ${ }^{18}$

b. Kerangka Dasar Kurikulum 2013

Pengembangan kurikulum 2013 dilandasi secara filosofis, yuridis, dan konseptual. ${ }^{19}$ Landasan Filosofis terdiri dari filosofis tan 70 Tabun Taman Siswa, (Yogyakarta:MLPTS, 1992, hlm. 302-303.

${ }^{16}$ Ki Hadjar Dewantara, Op.Cit., hlm. XIII

${ }^{17}$ Mulyoto, Strategi Pembelajaran Di Era Kurikulum 2013, (Jakarta: Prestasi Pustakaraya, 2013), hlm. 102-104.

${ }^{18}$ Kemendikbud. Materi Pelatihan Guru Implementasi Kurikulum 2013 Tabun 2014. (Jakarta: Badan Pengembangan Sumber Daya Manusia Pendidikan dan Kebudayaan dan Penjaminan Mutu Pendidikan Kementerian Pendidikan dan Kebudayaan, 2014), hlm. 2-3

19 H.E. Mulyasa, Pengembangan dan Implementasi Kurikulum 2013, (Ban - 
pancasila yang memberikan berbagai prinsip dasar dalam pembangunan pendidikan. Filosopi pendidikan yang berbasis pada nilai-nilai luhur, nilai akademik, kebutuhan peserta didik, dan masyarakat. Landasan Yuridis terdiri dari rencana pendidikan menengah nasional (RPJMN) 2010-2014 sektor Pendidikan. PP No. 19 tahun 2005 tentang standar nasional Pendidikan. INPRES Nomor 1 tahun 2010, tentang percepatan pelaksanaan prioritas pembangunan nasional, penyempurnaan kurikulum dan metode pembelajaran aktif berdasarkan nilai-nilai budaya bangsa untuk membentuk daya saing dan karakter bangsa.

Landasan konseptual, terdiri dari relevansi Pendidikan (link and match), kurikulum berbasis kompetensi dan karakter, pembelajaran kontekstual (contextual teaching and learning), pembelajaran aktif (student active learning), penilaian yang valid, utuh dan menyeluruh.

c. Elemen Perubahan Kurikulum 2013

Perubahan yang terdapat pada kurikulum 2013 yaitu jumlah mata pelajaran dan jumlah jam belajar mulai dari tingkat SD-MI, SMP-MTS, SMA-MAN. ${ }^{20}$ Sementara menurut Abdul Majid, elemen perubahan kurikulum dilakukan pada empat komponen yaitu; standar kompetensi lulusan, standar isi, standar proses, dan standar penilaian. ${ }^{21}$

d. Proses Pembelajaran Kurikulum 2013

Proses pembelajaran Kurikulum 2013 terdiri atas pembelajaran intrakurikuler dan pembelajaran ekstrakurikuler. Proses pembelajaran intrakurikuler adalah proses pembelajaran yang berkenaan dengan mata pelajaran dalam struktur kurikulum dan dilakukan di kelas, sekolah, dan masyarakat. Pembelajaran ekstrakurikuler adalah kegiatan yang dilakukan untuk aktivitas

ung: Rosdakarya, Cetakan 1V, 2014), hlm. 64-65.

${ }^{20}$ Mida Latifatul Muzamiroh, Kupas Tuntas Kurikulum 2013; Kelebihan dan Kekurangan Kurikulum 2013, (Jakarta: Kata Pena, 2013), hlm. 142.

${ }^{21}$ Abdul Majid, Implementasi Kurikulum 2013; Kajian Teoritis dan Praktis, (Bandung; Interes, 2014), hlm. 41. 
yang dirancang sebagai kegiatan di luar kegiatan pembelajaran terjadwal secara rutin setiap minggu. Kegiatan ekstrakurikuler terdiri atas kegiatan wajib dan pilihan. Pramuka adalah kegiatan ekstrakurikuler wajib. Kegiatan ekstrakurikuler wajib dinilai yang hasilnya digunakan sebagai unsur pendukung kegiatan intrakurikuler. ${ }^{22}$

\section{Metodologis}

Penelitian ini merupakan kajian studi pustaka dengan menggunakan pendekatan content analysis (analisis isi). Sumber data dalam penelitian ini berupa sumber primer dan sumber sekunder. Sumber primer meliputi kumpulan karya Ki Hajar Dewantara dan Buku yang dibuat Kemendikbud tentang implementasi kurikulum 2013. Sumber sekunder berupa tulisan atau karya orang lain tentang $\mathrm{Ki}$ Hajar Dewantara dan implementasi kurikulum 2013. Pengumpulan data dilakukan dengan teknik library research (penelitian pustaka). Data yang telah terkumpul kemudian dianalisis secara kualitatif dengan pendekatan induktif dengan mengacu pada permasalahan yang ada.

\section{Pemikiran Pendidikan Ki. Hajar Dewantara dan Relevansinya dengan Kurikulum 2013}

\section{Tujuan Pendidikan}

Tujuan pendidikan merupakan masalah sentral dalam pendidikan, sebab tanpa perumusan yang jelas tentang tujuan pendidikan, maka kegiatan pendidikan menjadi tanpa arah bahkan dapat salah langkah, oleh karena itu perumusan tujuan pendidikan dengan jelas dan tegas sejak awal menjadi bagian yang sangat penting untuk dilakukan.

Menurut Ki Hadjar Dewantara pendidikan sebagai tuntunan di dalam hidup tumbuhnya anak-anak, artinya pendidikan menuntun segala kekuatan kodrat yang ada pada anak-anak itu, agar mereka sebagai manusia dan sebagai anggota

${ }^{22}$ Kemendikbud, Op.Cit, hlm. 9-10 
Pemikiran Pendidikan Ki. Hajar Dewantara dan Relevansinya....

masyarakat dapatlah mencapai keselamatan dan kebahagiaan yang setinggi-tingginya. ${ }^{23}$ Pendidikan sebagai tuntunan tidak hanya menjadikan seorang anak mendapat kecerdasan yang lebih tinggi dan luas, tetapi juga menjauhkan dirinya dari perbuatan jahat. ${ }^{24}$

Manusia merdeka merupakan tujuan pendidikan Ki Hadjar Dewantara, merdeka baik secara fisik, mental, dan kerohanian. Kemerdekaan pribadi dibatasi oleh tertib damai kehidupan bersama, dan ini mendukung sikap-sikap seperti keselarasan, kekeluargaan, musyawarah, toleransi, kebersamaan, demokrasi, tanggungjawab, dan disiplin. ${ }^{25}$ Manusia merdeka adalah seseorang yang mampu berkembang secara utuh dan selaras dari segala aspek kemanusiaanya dan yang mampu menghargai dan menghormati kemanusiaan setiap orang. ${ }^{26}$

Selanjutnya tujuan kurikulum 2013 bertujuan untuk mempersiapkan manusia Indonesia agar memiliki kemampuan hidup sebagai pribadi dan warga Negara yang beriman, produktif, kreatif, inovatif, dan afektif serta mampu berkontribusi pada kehidupan masyarakat, berbangsa, bernegara, dan peradaban dunia. ${ }^{27}$ Pengembangan kurikulum 2013 diharapkan akan menghasilkan insan Indonesia yang produktif, kreatif, inovatif, afektif; melalui penguatan sikap, keterampilan, dan pengetahuan yang terintegrasi. Dalam hal ini, pengembangan kurikulum difokuskan pada pembentukan kompetensi dan karakter peserta didik, berupa paduan pengetahuan, keterampilan dan sikap yang dapat didemonstrasikan peserta didik sebagai wujud pemahaman terhadap konsep yang dipelajarinya secara kontekstual. ${ }^{28}$ Tujuan tersebut, menunjukkan arah, dan proses penyelenggaraan pendidikan yang sejatinya berkualitas dan berbasis karakter.

${ }^{23}$ Ki Hadjar Dewantara, Menuju Manusia Merdeka, (Yogyakarta: Leutika, 2009), hlm. 15.

${ }^{24}$ Suparto Rahardjo, Op.Cit, hlm. 70.

${ }^{25}$ Wawan Eko Mujito, Op.Cit., hlm. 70.

${ }^{26}$ Suparto Rahardjo, Op.Cit, hlm. 85

${ }^{27}$ Heri Widyastono, Op.Cit, hlm. 131

${ }^{28}$ H.E. Mulyasa, Op.Cit.,hlm. 65 


\section{Eka Yanuarti}

Kemampuan hidup dipahami sebagai kualitas sikap spiritual dan sosial dan kecakapan pengembangan pengetahuan serta penerapannya.

Tujuan pendidikan dapat diklasifikasikan menjadi empat dimensi yaitu tujuan jasmani (al-abdaf al-jismiyyah), tujuan rohaniah (al-ahdaf al-rubaniyyah), tujuan akal (al-ahdaf alaqliyah), tujuan sosial (al-abdaf al-Ijtima'iyyah). ${ }^{29}$ Berdasarkan pemaparan di atas dapat dipahami tujuan pendidikan yang dikemukakan oleh Ki. Hajar Dewantara sejalan dengan tujuan kurikulum 2013, yaitu; sama-sama mengarahkan tujuan pendidikan dalam empat dimensi, yaitu tujuan jasmani, akal, rohani dan sosial, namun terdapat perbedaan dalam penjabaran dan penekanan dalam menjelaskan masing-masing dimensi tujuan pendidikan, yaitu; Pertama, Dimensi Jasmani, Ki. Hajar dewantara mengarahkan pada kemerdekaan fisik, yang menghendaki fisik yang sehat dan kuat, sementara kurikulum 2013, mengarahkan pada pencapaian jasmani yang produktif, kreatif, inovatif. Ke Dua, Dimensi Akal, Ki. Hajar dewantara mengarahkan pendidikan pada pencapaian kecerdasan yang lebih tinggi dan luas, sementara kurikulum 2013 mengarahkan pada pengembangan pengetahuan serta penerapannya. Ke Tiga, Dimensi Rohani, Ki. Hajar Dewantara mengarahkan pada pencapaian keselamatan dan kebahagiaan yang setinggi-tingginya dengan mencapai kemerdekaan mental dan kerohanian, sementara kurikulum 2013 mengarahkan pada pencapaian sebagai warga Negara yang beriman dan memiliki kecerdasan afektif. Ke Empat Dimensi Sosial, Ki. Hajar Dewantara mendukung tercapainya sikap-sikap keselarasan, kekeluargaan, musyawarah, toleransi, kebersamaan, demokrasi, tanggungjawab, dan disiplin, sementara kurikulum 2013 mengarahkan pada pencapaian kemampuan memberi kontribusi pada kehidupan masyarakat, berbangsa, bernegara, dan peradaban dunia.

${ }^{29}$ Bukhari Umar, Ilmu Pendidikan Islam, (Jakarta: Amzah, 2010), hlm. 59- 60 . 
Tujuan pendidikan yang dikemukakan oleh Ki. Hajar Dewantara sejalan dengan tujuan kurikulum 2013, yaitu; sama-sama mengarahkan tujuan pendidikan berkaitan dengan individu dan masyarakat, yaitu Pertama, Tujuan pendidikan yang berkaitan dengan individu, Ki. Hajar Dewantara mengarahkan pada kemerdekaan baik secara fisik, mental, dan kerohanian, sementara kurikulum 2013 tidak hanya merdeka secara fisik, tetapi mempersiapkan manusia Indonesia agar memiliki kemampuan hidup sebagai pribadi dan warga Negara yang beriman, produktif, kreatif, inovatif, dan afektif. Ke Dua, Tujuan pendidikan yang berkaitan dengan masyarakat, Ki. Hajar Dewantara mendukung sikap-sikap seperti keselarasan, kekeluargaan, musyawarah, toleransi, kebersamaan, demokrasi, tanggungjawab, dan disiplin, sementara kurikulum 2013 tidak hanya mengarahkan kontribusi dalam masyarakat, tetapi lebih luas lagi yaitu berkontribusi pada bangsa, negara, bahkan peradaban dunia.

2. Pendidik

Menurut Ki. Hajar Dewantara mendidik dalam arti yang sesungguhnya adalah proses memanusiakan manusia, yakni pengangkatan manusia ke taraf insani. Mendidik harus lebih memerdekakan manusia dari aspek hidup batin (otonomi berpikir dan mengambil keputusan, martabat, mentalitas demokratik). ${ }^{30}$ Ki Hadjar Dewantara memberikan beberapa pedoman dalam menciptakan kultur positif seorang pendidik. Semboyan Trilogi pendidikan memiliki arti yang melibatkan seluruh pelaku pendidikan atau guru dan peserta didik adalah: Tut wuri handayani, dari belakang seorang guru harus bisa memberikan dorongan dan arahan. Ing madya mangun karsa pada saat di antara pesetra didik, guru harus menciptakan prakarsa dan ide. Ing ngarsa sung tulada, berarti ketika guru berada di depan, seorang guru harus memberi teladan atau contoh dengan tindakan yang baik. ${ }^{31}$

\footnotetext{
${ }^{30}$ Ki Hadjar Dewantara, Menuju Manusi Merdeka,. hal. 3

${ }^{31}$ Wawan Eko Mujito, Op.Cit, hlm. 69
} 
Kata kunci kedua yang menentukan keberhasilan implementasi kurikulum 2013 adalah kreativitas pendidik. Tugas pendidik tidak hanya menyampaikan informasi kepada peserta didik, tetapi harus kreatif memberikan layanan dan kemudahan belajar kepada seluruh peserta didik, agar mereka dapat belajar dalam suasana yang menyenangkan, gembira dan penuh semangat, tidak cemas, dan berani mengemukakan pendapat secara terbuka. Peran guru tidak hanya menjadi fasilitator dalam pembelajaran, tetapi juga menjadi mitra belajar bagi peserta didik. ${ }^{32}$

Beberapa hal yang perlu dimiliki pendidik, untuk mendukung implementasi kurikulum 2013, yaitu menguasai dan memahami kompetensi inti dalam hubungannya dengan kompetensi lulusan. Menyukai apa yang diajarkannya dan menyenangi mengajar sebagai suatu profesi. Memahami peserta didik, pengalaman, kemampuan, dan prestasinya. Menggunakan metode dan media yang bervariasi dalam mengajar dan membentuk kompetensi peserta didik. Memodifikasi dan mengeliminasi bahan yang kurang penting bagi kehidupan peserta didik. Mengikuti perkembangan pengetahuan mutakhir. Menyiapkan proses pembelajaran. Mendorong peserta didik untuk memperoleh hasil yang lebih baik. Menghubungkan pengalaman yang lalu dengan kompetensi dan karakter yang akan dibentuk. ${ }^{33}$

Berdasarkan pemamparan di atas, dapat dipahami menurut Ki. Hajar dewantara pendidik terdiri dari orang tua, guru atau pemimpin, termasuk pemimpin spiritual, peran pendidik yaitu sebagai fasilitator dan motivator. Sementara menurut kurikulum 2013 peran pendidik juga sebagai fasilitator dalam pembelajaran, tetapi sedikit berbeda dengan ki. Hajar dewantara, kurikulum 2013 menjadikan pendidik sebagai mitra belajar bagi peserta didik.

Relevansi ini tidak hanya dianalisis dari peran guru, tetapi berdasarkan kompetensi yang harus dimiliki guru, berdasarkan Undang-undang Nomor 14 Tahun 2005 tentang Guru dan Dosen

\footnotetext{
${ }^{32}$ Mulyasa, Op.Cit, hlm. 44

${ }^{33} \mathrm{Ibid}, \mathrm{hlm} .44$
} 
pada pasal 10 ayat 1 menyatakan bahwa "Kompetensi guru meliputi Kompetensi Pedagogik, Kompetensi Kepribadian, Kompetensi Sosial, dan Kompetensi Profesional. ${ }^{34}$ Berdasarkan pemaparan di atas, diketahui Ki. Hajar Dewantara secara tersirat telah memaparkan empat kompetensi tersebut harus dimiliki seorang pendidik, begitu juga dengan kurikulum 2013, namun terdapat perbedaan dalam penjabaran dan penekanan dalam menjelaskan masing-masing kompetensi, yaitu;

Pertama, Kompetensi Pedagogik, menurut Ki. Hajar Dewantara, seperti semboyannya Tut Wuri Handayani, dari belakang seorang pendidik harus dapat memberikan dorongan dan arahan. Kemudian, Ing Madya Mangun Karsa pada saat di antara pesetra didik, pendidik harus menciptakan prakarsa dan ide. sementara kurikulum 2013 menjabarkan lebih panjang tentang kompetensi ini, seperti; pendidik hendaknya menguasai dan memahami kompetensi inti dalam hubungannya dengan kompetensi lulusan. Pendidik menyukai apa yang diajarkannya dan menyenangi mengajar sebagai suatu profesi. Pendidik memahami peserta didik, pengalaman, kemampuan, dan prestasinya. Pendidik menyiapkan proses pembelajaran, Pendidik mendorong peserta didik untuk memperoleh hasil yang lebih baik, Pendidik memperhatikan perbedaan individual peserta didik. Pendidik memiliki banyak pengetahuan, inisiatif, kreatif dan dan banyak akal.

Ke dua, Kompetensi Kepribadian, menurut Ki. Hajar Dewantara, seperti semboyannya yaitu Ing Ngarsa Sung Tulada, berarti ketika pendidik berada di depan, seorang guru harus memberi teladan atau contoh dengan tindakan yang baik, kemudian pendidik membangun suatu etos kerja yang positif yaitu menjunjung tinggi pekerjaan; menjaga harga diri dalam melaksanakan pekerjaan, dan keinginan untuk melayani masyarakat, sementara menurut kurikulum 2013, pendidik harus respek dan memahami dirinya, serta dapat mengontrol dirinya (emosi dan stabil). Pendidik hanydaknya antusias dan bergairah

${ }^{34}$ Afnil. Guza, Op.Cit., hlm. 57. 


\section{Eka Yanuarti}

terhadap bahan, kelas dan seluruh kegiatan pembelajaran; pendidik tidak boleh menonjolkan diri dan hendaknya menjadi teladan bagi peserta didik.

Ke tiga, Kompetensi Sosial, menurut Ki. Hajar Dewantara pendidik memiliki keunggulan dalam hubungan (relasi dan komunikasi) dengan peserta didik, dan anggota komunitas sekolah, dan juga relasi dan komunikasi dengan pihak lain (orang tua, komite sekolah, pihak terkait), sementara menurut kurikulum 2013, pendidik harus dapat berbicara dengan jelas dan komunikatif (dapat mengkomunikasikan idenya terhadap peserta didik. Pendidik harus menghindari sarkasme dan ejekan terhadap peserta didik..

Ke empat, Kompetensi Profesional, menurut Ki. Hajar Dewantara pendidik harus memiliki penampilan yang profesional secara fisik, intelektual, relasi sosial, kepribadian, nilai-nilai dan kerohanian, serta mampu menjadi motivator. Sementara kurikulum 2013 Pendidik dapat menggunakan metode dan media yang bervariasi dalam mengajar dan membentuk kompetensi peserta didik. Pendidik mampu memodifikasi dan mengeliminasi bahan yang kurang penting bagi kehidupan peserta didik. Pendidik mengikuti perkembangan pengetahuan mutakhir. Pendidik menghubungkan pengalaman yang lalu dengan kompetensi dan karakter yang akan dibentuk.

3. Prinsip Pembelajaran

Prinsip dimaksudkan sebagai asas atau kebenaran yang menjadi pokok dasar orang berpikir, bertindak, dan sebagainya. Dalam Pembelajaran, prinsip-prinsip belajar dapat mengungkapkan batas-batas kemungkinan dalam pembelajaran. Dalam melaksanakan kegiatan pembelajaran, prinsip-prinsip pembelajaran akan membantu pendidik dalam memilih tindakan yang tepat sehingga dapat terhindar dari tindakan yang kelihatan 
Pemikiran Pendidikan Ki. Hajar Dewantara dan Relevansinya....

baik, justru akan merugikan siswa atas pencapain keberhasilan pembelajaran. ${ }^{35}$

Menurut Ki Hadjar Dewantara dalam melaksanakan proses pendidikan di Taman siswa, berlandaskan pada lima prinsip, yang disebut "Panca Darma". Panca Darma ini memuat perincian baik berasal dari asas-asas yang dipakai di dalam Taman siswa sejak berdirinya pada tahun 1922 hingga seterusnya, maupun yang terdapat dalam segala peraturan-peraturan dan berbagai adat istiadat dalam hidup dan penghidupan Taman siswa. ${ }^{36}$ Berikut ini lima prinsip pembelajaran yang dikemukakan oleh Ki. Hajar Dewantara, yaitu;

a) Prinsip Kemerdekaan

Kemerdekaan atau kemampuan pribadi bertujuan agar peserta didik dapat leluasa mengembangkan cipta, rasa, dan karsa dalam proses belajar. Hal ini selaras dengan semboyan "Tutwuri Handayani”. Yang berarti mengikuti dari belakang dan memberikan pengaruh. Mengikuti dari belakang berarti memberikan kebebasan kepada anak didik tanpa meninggalkan pengawasan. Sehingga anak didik tidak bebas lepas tanpa pengawasan dan juga tidak terkekang atau terhambat dalam pertumbuhan dan perkembangannya sebagai manusia merdeka. ${ }^{37}$

b) Prinsip Kebangsaan

Belajar juga harus sesuai dengan prinsip kebangsaan karena peserta didik akan hidup dan berinteraksi dengan masyarakat luas. Prinsip kebangsaan tidak boleh bertentangan dengan kemanusiaan, oleh karena itu mengandung rasa satu dengan bangsa sendiri, rasa satu dalam suka dan duka, rasa satu dalam kehendak menuju kepada kebahagiaan lahir dan batin seluruh bangsa. Pengembangan rasa kebangsaan bukan berarti

${ }^{35}$ Jamil Suprihatiningrum, Strategi Pembelajaran (Teori dan Aplikasi), (Yo yakarta; Arr-Ruzz Media, 2012), hlm. 99

${ }^{36} \mathrm{Ki}$ Hadjar Dewantara, Asas-asas dan Dasar-dasar Taman Siswa, (Yogy karta: Majelis Luhur Taman Siswa, 1964), hlm. 7.

${ }^{37}$ Ki Hadjar Dewantara, Karya Bagian I Pendidikan, Op. Cit., hlm. 4 


\section{Eka Yanuarti}

menafikkan bangsa lain, menjauhkan bangsa lain. Namun yang dimaksud dengan mengembangkan nasionalisme yaitu memupuk rasa kebangsaan sendiri dalam membina pergaulan dan kerja sama dengan bangsa lain di dunia. ${ }^{38}$

c) Prinsip Kebudayaan

Belajar juga harus sesuai dengan prinsip kebudayaan tempat agar hasil belajar bisa diterima di lingkungan tempat tinggal. Prinsip ini dipakai untuk membimbing anak didik agar tetap menghargai serta mengembangkan kebudayaan sendiri. Manakala ada kebudayaan yang dapat memperindah, memperhalus dan meningkatkan kualitas kehidupan, hendaknya diambil. Tetapi jika berpengaruh sebaliknya, sebaiknya ditolak.

d) Prinsip Kemanusiaan

Peserta didik juga dituntut untuk tidak melanggar dasar hak asasi manusia. Dasar kemanusiaan ialah berusaha mengembangkan sifatsifat luhur manusia. Hidup bersama atas dasar kegotongroyongan dan saling mengasihi dan saling mengasuh dan membimbing agar bisa menjadi pribadi yang baik. Oleh karena itu dalam pelaksanaan dan selalu diorientasikan untuk kepentingan bersama.

e) Prinsip Kodrat alam

Prinsip Kodrat alam bertujuan agar peserta didik tidak melalaikan kewajibanya baik kewajiban terhadap Tuhan, Lingkungan, masyarakat, maupun diri sendiri. Ki Hajar Dewantara melaksanakan pendidikan budi pekerti dengan cara "Tutwuri Handayani", yang dikenal dengan sistem Among. (Among berarti asuhan dan pemeliharaan dengan suka duka dengan memberi kebebasan anak asuhan bergerak menurut kemauannya. ${ }^{39}$

${ }^{38} \mathrm{Ki}$ Hadjar Dewantara, Asas-asas dan Dasar-dasar Taman Siswa, dalam Buku Peringatan Taman Siwa 30 Tabun, (Yogyakarta: MLPTS, 1952), hlm. 58

${ }^{39}$ Moh. Tauchid, Perjuangan dan Ajaran Hidup Ki Hadjar Dewantara, (Yo yakarta: MLPTS, 1963), hlm. 36. 
Pemikiran Pendidikan Ki. Hajar Dewantara dan Relevansinya....

Menurut Kaimuddin kurikulum 2013 dikembangkan dengan karakteristik sebagai berikut; Mengembangkan keseimbangan antara pengembangan sikap spiritual dan sosial, rasa ingin tahu, kreativitas, kerja sama dengan kemampuan intelektual dan psikomotorik. Sekolah merupakan bagian dari masyarakat yang memberikan pengalaman belajar yang terencana dimana peserta didik menerapkan apa yang dipelajari di sekolah ke masyarakat dan memanfaatkan masyarakat sebagai sumber belajar. Mengembangkan sikap, pengetahuan, dan keterampilan serta menerapkannya dalam berbagai situasi di sekolah dan masyarakat. Memberi waktu yang cukup leluasa untuk mengembangkan berbagai sikap, pengetahuan, dan keterampilan. Kompetensi dinyatakan dalam bentuk kompetensi inti kelas yang dirinci lebih lanjut dalam kompetensi dasar mata pelajaran. Kompetensi inti menjadi unsur pengorganisasian (organizing elements) kompetensi dasar, dimana semua kompetensi dasar dan proses pembelajaran dikembangkan untuk mencapai kompetensi yang dinyatakan dalam kompetensi inti. Kompetensi dasar yang dikembangkan didasarkan pada prinsip akumulatif, saling memperkuat (enforced) dan memperkaya (enriched) antar mata pelajaran dan jenjang pendidikan (organisasi vertikal dan horizontal. ${ }^{40}$

Berdasarkan pemaparan di atas, prinsip pembelajaran yang ada di kurikulum 2013 relevan dengan prinsip pembelajaran menurut Ki. Hajar dewantara, yaitu: Pertama, prinsip kemerdekaan; kurikulum 2013 dikembangkan dengan memberikan kesempatan kepada peserta didik untuk mengembangkan perbedaan dalam kemampuan dan minat. Ke dua, prinsip kebangsaan; kurikulum 2013 didasarkan kepada kepentingan nasional dan kepentingan daerah. Ke tiga, prinsip kebudayaan; kurikulum 2013 berpusat pada potensi, perkembangan, kebutuhan, dan kepentingan peserta didik dan lingkungannya, kurikulum 2013 harus diarahkan kepada proses pengembangan, pembudayaan dan pemberdayaan

${ }^{40}$ Kaimuddin, Implementasi Pendidikan Karakter dalam Kurikulum 2013, Ju nal Dinamika Ilmu Vol. 14. No 1, Juni 2014, hlm. 58. 


\section{Eka Yanuarti}

peserta didik yang berlangsung sepanjang hayat. Ke empat, prinsip kodrat alam; kurikulum 2013 harus relevan dengan kebutuhan kehidupan, kurikulum 2013 harus tanggap terhadap perkembangan ilmu pengetahuan, budaya, teknologi, dan seni. Ke lima, prinsip kemanusiaan, kurikulum dikembangkan berdasarkan prinsip bahwa peserta didik berada pada posisi sentral dan aktif dalam belajar.

4. Materi Pembelajaran

Ki. Hajar Dewantara menekankan materi pembelajaran pada materi pendidikan budi pekerti. Materi pelajaran budi pekerti yang dikembangkan oleh Ki Hadjar Dewantara dapat diambil dari: bahan yang bersifat spontan, cerita rakyat/dongeng/legenda, lakon dalam pertunjukan sandiwara ataupun wayang, babad dan sejarah, cerita-cerita dalam buku-buku karya sastrawan/pujangga terkena, kitab-kitab suci agama, adat istiadat yang berlaku. ${ }^{41}$ Kemudian, materi tersebut diajarkan sesuai dengan tingkat perkembangan usia anak didik. Adapun materi pendidikan budi pekerti menurut Ki Hadjar Dewantara sebagai berikut : ${ }^{42}$

a. Taman Indria dan Taman Anak (5-8 Tahun); Materi atau isi pengajaran budi pekerti bagi anak yang masih di sekolah ini berupa latihan yang mengarah pada kebaikan yang memenuhi syarat bebas yaitu sesuai kodrat hidup anak.

b. Taman Muda (9-12 Tahun); anak-anak diberi peringatan tentang segala tingkah laku kebaikan dalam hidupnya sehari-hari.

c. Taman Dewasa (14-16 Tahun); anak mulai melatih diri dengan melakukan segala laku yang sulit dan berat dengan niat yang disengaja.

d. Taman Madya dan Taman Guru (17-20 Tahun); Dalam jenjang ini, mereka mendapatkan pengajaran "ethik"

\footnotetext{
${ }^{41}$ Ki Hadjar Dewantara, Karya Bagian I Pendidikan, Loc.Cit., hlm. 490

${ }^{42} \mathrm{Ki}$ Hadjar Dewantara, Karya Bagian I Pendidikan, Loc.Cit., hlm. 487- 489
} 
yaitu hukum kesusilaan. Jadi tidak hanya bentuk-bentuk kesusilaan, tetapi juga tentang dasar-dasar kebangsaan, kemanusiaan, keagamaan, filsafat, kenegaraan, kebudayaan, adat istiadat dan sebagainya.

Sementara, dalam kurikulum 2013 perlu dilakukan langkah penguatan materi dengan mengevaluasi ulang ruang lingkup materi yang terdapat di dalam kurikulum dengan cara meniadakan materi yang tidak esensial atau tidak relevan bagi peserta didik, mempertahankan materi yang sesuai dengan kebutuhan peserta didik, dan menambahkan materi yang dianggap penting dalam perbandingan internasional. ${ }^{43}$ penghapusan terjadi pada mata pelajaran, melainkan pada materinya. Materi-materi yang dirasa belum waktunya untuk diberikan seyogyanya dieliminasi. Jadi, hanya materi-materi yang benar-benar berguna bagi anak didik dan sesuai dengan tingkat perkembangan mereka sajalah yang diberikan. ${ }^{44}$

Tingkat SD, terdapat 8 (delapan) mata pelajaran, yaitu: Pendidikan Agama dan Budi Pekerti, Pendidikan Kewarganegaraan, Bahasa Indonesia, Matematika, Seni Budaya, Pendidikan JasmaniOlahraga, IPA, IPS, Muatan Lokal, bahkan semula rencananya hanya enam mata pelajaran saja, karena IPA dan IPS rencananya diintegrasikan ke mata pelajaran lainnya. Tingkat SMP, terdapat 10 (sepuluh) mata pelajaran yaitu: Pendidikan Agama dan Budi Pekerti, PPKn, Bahasa Indonesia, Matematika, IPA, IPS, Bahasa Inggris, Seni Budaya dan Prakarya (termasuk Muatan Lokal), Pendidikan Jasmani OR dan Kes (termasuk Muatan Lokal), dan Prakarya (termasuk Muatan Lokal).

Untuk SMA, terdapat tiga kelompok mata pelajaran yaitu kelompok A (wajib) terdiri dari Pendidikan Agama dan Budi Pekerti, Pendidikan Pancasila dan Kewarganegaraan, Bahasa Indonesia, Matematika, Sejarah Indonesia, Bahasa

\footnotetext{
${ }^{43}$ Kemendikbud, hlm.

${ }^{44}$ Mulyasa Op.,Cit, hlm. 106-108
} 


\section{Eka Yanuarti}

Inggris. Kelompok B (wajib) terdiri dari Seni Budaya, Prakarya, Pendidikan Jasmani, Olahraga dan Kesehatan. Kelompok C (Permintaan) terdiri dari Mata Pelajaran Permintaan akademik (untuk SMA) dan Mata Pelajaran permintaan akademik dan Vokasi (untuk SMK). ${ }^{45}$

Dari pemaparan di atas, dapat dipahami, materi pembelajaran yang ditetapkan kurikulum 2013 relevan dengan pemikiran pendidikan Ki. Hajar dewantara, yaitu materi pembelajaran diajarkan sesuai dengan tingkat perkembangan usia peserta didik. Kemudian mata pelajaran yang terdapat pada kurikulum 2013 juga relevan dengan pemikiran pendidikan Ki. Hajar Dewantara, dengan meletakkan mata pelajaran pendidikan Agama dan Budi Pekerti di setiap jenjang satuan pendidikan, mulai dari tingkat SD, SMP, SMA hingga perguruan tinggi atau dalam pemikiran Ki. Hajar Dewantara yaitu Taman Indria dan Taman Anak (5-8 Tahun), Taman Muda (9-12 Tahun), Taman Dewasa (14-16 Tahun), Taman Madya dan Taman Guru (17-20 Tahun).

\section{Metode Pembelajaran}

Metode Pembelajaran yang digunakan Ki. Hajar Dewantara adalah sistem Among. Among memiliki pengertian menjaga, membina, dan mendidik anak dengan kasih sayang. Pelaksana Among disebut Pamong, yang mempunyai kepandaian dan pengalaman lebih dari yang diamong. Sistem Among dalam belajar mengajar dengan metode kinder spellen (permainan anak) atau belajar sambil bermain secara berkelompok yang bermanfaat untuk mendidik interaksi sosial kepada peserta didik. ${ }^{46}$

Ada tiga metode yang dipakai oleh Ki Hadjar Dewantara dalam mengajarkan budi pekerti berdasarkan urutan-urutan pengambilan keputusan berbuat artinya kita bertindak sebaiknya berdasarkan urutanyang benar, sehingga tidak ada penyesalan

\footnotetext{
${ }^{45}$ Ibid, hlm. 87-93.

${ }^{46}$ Suparto Rahardjo, Op.Cit, hlm. 72.
} 
di kemudian hari. Tiga metode tersebut adalah: ngerti, ngrasa dan nglakoni. ${ }^{47}$ Pertama, Metode ngerti maksudnya adalah memberikan pengertian yang sebanyak-banyaknya kepada anak. Di dalam pendidikan budi pekerti anak diberikan pengertian tentang baik dan buruk. Di samping itu juga diajarkan tentang aturan yang berlaku dalam kehidupan masyarakat, berbangsa dan bernegara serta beragama. Kedua, Metode ngrasa maksudnya adalah berusaha semaksimal mungkin untuk memahami dan merasakan tentang pengetahuan yang diperolehnya. Dalam hal ini anak didik untuk dapat memperhitungkan dan membedakan antara yang benar dan yang salah. Ketiga, Metode nglakoni maksudnya adalah mengerjakan setiap tindakan, tanggung jawab telah dipikirkan akibatnya berdasarkan pengetahuan yang telah didapatnya. Jika sudah mantap dengan tindakan yang akan dilakukan hendaknya segera dilakukan jangan ditunda-tunda.

Pembelajaran yang direkomendasikan oleh kurikulum 13 adalah pembelajaran tematik-intergratif. Pendekatan pembelajaran yaitu pendekatan saintifik. Model pembelajaran yang digunakan pembelajaran berbasis proyek (Project Based Learning), pembelajaran berbasis masalah (Problem Based Learning), pembelajaran berbasis penemuan (Discovery Learning). ${ }^{48}$ Berikut ini akan dibahas lebih lanjut;

Pembelajaran tematik terpadu (PTP) atau integrated thematic instruction (ITI) dikembangkan pertama kali pada awal tahun 1970-an. Belakangan PTP diyakini sebagai salah satu model pembelajaran yang efektif (bighly effective teachingmodel) karena mampu mewadahi dan menyentuh secara terpadu dimensi emosi, fisik, dan akademik peserta didik di dalam kelas atau di lingkungan sekolah. PTP pada awalnya dikembangkan untuk anak-anak berbakat dan bertalenta (gifted and talented), anak-anak yang cerdas, program perluasan belajar, dan peserta didik yang

${ }^{47}$ Muhammad Tauchid, Perjuangan Hidup Ki Hadjar Dewantara, (Yogy karta: Mlpts, 1963), hlm. 57.

${ }^{48}$ Kemendikbud, Op.Cit, hlm. 15-33. 


\section{Eka Yanuarti}

belajar cepat. PTP ini pun sudah terbukti secara empirik berhasil memacu percepatan dan meningkatkan kapasitas memori peserta didik (enhance learning and increase long-term memory capabilities of learners) untuk waktu yang panjang). ${ }^{49}$

Pendekatan saintifik diyakini sebagai titian emas perkembangan dan pengembangan sikap, keterampilan, dan pengetahuan peserta didik. Dalam pendekatan atau proses kerja yang memenuhi kriteria ilmiah, para ilmuan lebih mengedepankan penalaran induktif (inductive reasoning) dibandingkan dengan penalaran deduktif (deductivereasoning). Metode ilmiah pada umumnya memuat serangkaian aktivitas pengumpulan data melalui observasi atau ekperimen, mengolah informasi atau data, menganalisis, kemudian memformulasi, dan menguji hipotesis. ${ }^{50}$

Pembelajaran berbasis masalah (Problem Based Learning) adalah model pembelajaran yang berfokus pada konsep-konsep dan prinsip-prinsip utama (cetral) dari suatu disiplin, melibatkan siswa dalam kegiatan pemecahan masalah dan tugas-tugas bermakna lainnya, memberi peluang siswa bekerja, secara otonom mengkonstruk belajar mereka sendiri, dan puncaknya menghasilkan produk karya siswa bernilai dan realistik. ${ }^{51}$

Pembelajaran berbasis masalah (Problem Based Learning) adalah serangkain aktivitas pembelajaran yang menekankan pada proses penyelesaian masalah yang dihadapi secara ilmiah. Ilmiah dipecahkan melalui proses berpikir deduktif dan induktif. Proses berpikir ini dilakukan secara sistematis dan empiris (disadarkan pada data dan fakta yang jelas). ${ }^{52}$ Pembelajaran berbasis penemuan (Discovery Learning) adalah proses mental dimana siswa menghasilkan suatu konsep atau suatu prinsip. Proses mental,

\footnotetext{
${ }^{49}$ Ibid, hlm. 15.

${ }^{50}$ Ibid, hlm. 18

${ }^{51}$ Ngalimun, Strategi dan Model Pembelajaran, (Yogyakarta; Aswaja Pres -
} indo, 2014), hlm. 185.

${ }^{52}$ Jumanta Hamdayama, Model dan Metode Pembelajaran Kreatif dan Berkar kter, (Bogor; Ghalia Indonesia, 2014), hlm. 209. 
Pemikiran Pendidikan Ki. Hajar Dewantara dan Relevansinya....

misalnya; mengamati, menjelaskan, mengelompokkan, membuat hipotesa, membuat kesimpulan, dan sebagainya. ${ }^{53}$

Dari pemaparan di atas, dapat dipahami, alur pembelajaran yang ada pada kurikulum 2013 relevan dengan metode pembelajaran yang dikemukakan Ki. Hajar Dewantara yaitu; Pertama, pembelajaran tematik-intergratif pada kurikulum 2013 relevan dengan metode ngerti yang dijelaskan oleh Ki Hajar Dewantara, pada pembelajaran ini diberikan pengertian yang sebanyak-banyaknya kepada peserta didik. Pembelajaran ini mampu mewadahi dan menyentuh secara terpadu dimensi emosi, fisik, dan akademik peserta didik di dalam kelas atau di lingkungan sekolah. Ke dua, pendekatan saintifik pada kurikulum 2013 relevan dengan metode ngrasa yang dijelaskan oleh Ki Hajar Dewantara, pendekatan ini berusaha semaksimal mungkin untuk memahami dan merasakan tentang pengetahuan yang diperolehnya. Pendekatan ini harus di isi dengan aktivitas pengumpulan data melalui observasi atau ekperimen, mengolah informasi atau data, menganalisis, kemudian memformulasi, dan menguji hipotesis.

Ke tiga, Model pembelajaran berbasis proyek (Project Based Learning) pada kurikulum 2013 relevan dengan metode nglakoni yang dijelaskan Ki. Hajar Dewantara, setiap tindakan disertai tanggung jawab, apabila pengetahuan yang telah didapatnya sudah mantap hendaknya segera dilakukan jangan ditunda-tunda. Pada model pembelajaran ini melibatkan siswa dalam kegiatan pemecahan masalah dan tugas-tugas bermakna lainnya, memberi peluang siswa bekerja, secara otonom mengkonstruk belajar mereka sendiri, dan puncaknya menghasilkan produk karya siswa bernilai dan realistik.

\section{Simpulan}

Pemikiran pendidikan Ki. Hajar Dewantara relevan dengan kurikulum 2013 seperti tujuan pembelajaran, yaitu sama-

${ }^{53}$ Moh.Sholeh, Metodologi Pembelajaran Kontemporer, (Yogyakarta; Kaukaba, 2014), hlm. 228. 
sama mengarahkan tujuan pendidikan dalam empat dimensi, yaitu tujuan jasmani, akal, rohani dan sosial. Peran pendidik menurut Ki. Hajar Dewantara sebagai fasilitator dan motivator. Sementara menurut kurikulum 2013 peran pendidik juga sebagai fasilitator dalam pembelajaran dan sebagai mitra belajar bagi peserta didik. Keduanya sepakat bahwa ada empat kompetensi yang harus dimiliki seorang pendidik, yaitu pedagogik, kepribadian, sosial dan profesional. Prinsip pembelajaran yang ada di kurikulum 2013 relevan dengan prinsip pembelajaran menurut Ki. Hajar dewantara. Materi pembelajaran keduanya sepakat materi pembelajaran diajarkan sesuai dengan tingkat perkembangan usia peserta didik. Kemudian mata pelajaran yang terdapat pada kurikulum 2013 juga relevan dengan pemikiran pendidikan Ki. Hajar Dewantara, dengan meletakkan mata pelajaran pendidikan Agama dan Budi Pekerti di setiap jenjang satuan pendidikan. 


\section{Daftar Pustaka}

Aunurrahma, Belajar dan Pembelajaran, Bandung; Alfabeta, 2013.

Darsiti. Soeratman, Ki Hadjar Dewantara, Jakarta: Departemen Pendidikan dan Kebudayaan, 1983/1984.

Dewantara. Bambang,100 Tahun Ki Hadjar Dewantara, Jakarta: Pustaka Kartini, Cet.1, 1989.

Dewantara. Ki Hadjar, Karya Bagian I: Pendidikan, Yogyakarta: MLPTS, cet II, 1962.

Dewantara. Ki Hadjar, Menuju Manusia Merdeka, Yogyakarta: Leutika, 2009.

Dewantara, Ki Hadjar, Asas-asas dan Dasar-dasar Taman Siswa, Yogyakarta: Majlis Luhur Taman Siswa, 1964.

Ensiklopedi Nasional Indonesia, Jilid 4 Jakarta: 1989, Cipta Adi Pustaka, Cet. I.

Gunawan, Berjuang Tanpa Henti dan Tak Kenal Lelah Dalam Buku Peringatan 70 Tahun Taman Siswa, Yogyakarta: MLPTS, 1992.

Guza. Afnil, Undang-Undang Sistem Pendidikan Nasional dan UndangUndang Guru dan Dosen. Jakarta; Asa Mandiri, 2009.

Harahap. Hah. dan Bambang Sokawati Dewantara. Ki Hadjar Dewantara dan Kawan-Kawan, Ditangkap, Dipenjara, dan Diasingkan, Jakarta: Gunung Aguna, 1980.

Hariyadi. Ki, Ki Hadjar Dewantara sebagai Pendidik, Budayawan, Pemimpin Rakyat dalam Buku Ki Hadjar Dewantara dalam Pandangan Para Cantrik dan Mentriknya, Yogyakarta: MLTS,1989.

Izzati. Restu Sani, Implementasi Kurikulum 2013 bagi Peserta Didik Berkebutuhan Khusus Disekolah Dasar Inklusif, Pendidikan 
Luar Biasa, Fakultas Ilmu Pendidikan, Universitas Negeri Surabaya, 2015.

Jumanta Hamdayama, Model dan Metode Pembelajaran Kreatif dan Berkarakter, Bogor; Ghalia Indonesia, 2014.

Kaimuddin, Implementasi Pendidikan Karakter dalam Kurikulum 2013, Jurnal Dinamika Ilmu Vol. 14. No 1, Juni 2014.

Kemendikbud. Materi Pelatihan Guru Impelemntasi Kurikulum 2013 Tahun 2014. (Jakarta: Badan Pengembangan Sumber Daya Manusia Pendidikan dan Kebudayaan dan Penjaminan Mutu Pendidikan Kementerian Pendidikan dan Kebudayaan, 2014.

Majid. Abdul, Implementasi Kurikulum 2013; Kajian Teoritis dan Praktis, Bandung; Interes, 2014.

Muhammad Tauchid, Perjuangan Hidup Ki Hadjar Dewantara, Yogyakarta: MLPTS, 1963.

Mujito, Wawan Eko, Konsep Belajar Menurut Ki Hadjar Dewantara dan Relevansinya dengan Pendidikan Agama Islam, Jurnal Pendidikan Agama Islam, Vol. XI, No. 1, Juni 2014.

Mulyasa. H.E, Pengembangan dan Implementasi Kurikulum 2013, Bandung: Rosdakarya, Cetakan 1V, 2014.

Mulyoto, Strategi Pembelajaran Di Era Kurikulum 2013, Jakarta: Prestasi Pustakaraya, 2013.

Muthoifin, Pemikiran Pendidikan Multikultural Ki Hadjar Dewantara, Jurnal Intizar, Vol. 21, No. 2, 2015.

Muzamiroh, Mida Latifatul. Kupas Tuntas Kurikulum 2013; Kelebihan dan Kekurangan Kurikulum 2013, Jakarta: Kata Pena, 2013.

Ngalimun, Strategi dan Model Pembelajaran, Yogyakarta; Aswaja Pressindo, 2014.

Permana. Prastian Dwija, Pengaruh Penerapan Kurikulum 2013 terhadap Hasil Belajar Mata Diklat Pengelasan Kelas X TKR 
Pemikiran Pendidikan Ki. Hajar Dewantara dan Relevansinya....

di SMK Negeri 1 Sedan Rembang Tabun Ajaran 2013/2014” Universitas Negeri Semarang; urusan Teknik Mesin Fakultas'Teknik, 2013

Rahardjo. Suparto, Biografi Singkat Ki. Hajar Dewantara, 1889-1959, Yogyakarta: Garasi, 2009.

Soewito. Irna, H.N. Hadi, Soewardi Soeryaningrat dalam Pengasingan, Jakarta: Balai Pustaka, 1985.

Sholeh, Moh. Metodologi Pembelajaran Kontemporer, Yogyakarta: Kaukaba, 2014.

. Jamil, Strategi Pembelajaran (Teori dan Aplikasi), Yogyakarta; ArrRuzz Media, 2012.

Umar. Bukhari, Ilmu Pendidikan Islam, Jakarta: Amzah, 2010.

Widyastono. Heri, Pengembangan Kurikulum di Era Otonomi Daerah dari Kurikulum 2004, 2006, ke Kurikulum 2013, Jakarta: Bumi Aksara 2014. 
Eka Yanuarti

halaman ini bukan sengaja dikosongkan 